\title{
EDIÇÃO DIGITAL E ESTUDOS DAS CARTAS RELIGIOSAS NO CADERNO FARMÁCIA SÃO JOSÉ, DE EULÁLIO MOTTA
}

\author{
Stephanne da Cruz Santiago'; Patrício Nunes Barreiros $^{2}$ \\ 1. Bolsista PIBIC/CNPq/PROCAD, Graduando em Letras com Inglês, Universidade Estadual de Feira de Santana, e- \\ mail: stephannesantiago@gmail.com \\ 2. Orientador, Departamento de Letras e Artes, Universidade Estadual de Feira de Santana, e-mail: \\ patriciobarreiros@hotmail.com
}

PALAVRAS-CHAVE: Eulálio Motta, Edição Digital, Cartas.

\section{INTRODUÇÃO}

Eulálio de Miranda Motta (1907-1988), escritor baiano e natural de Mundo Novo, foi, além de poeta, jornalista e cronista, um missivista bastante ativo. Por meio de seus cadernos manuscritos, Eulálio Motta nos possibilitou o acesso aos rascunhos de suas cartas, e elas possuem importância tanto para o entendimento de aspectos de sua vida pessoal e relações interpessoais, quanto para a compreensão de sua obra.

O plano de trabalho 2015/2016 PIBIC/CNPq/AF propôs-se a edição dos textos do caderno Farmácia São José, de Eulálio Motta, e a partir dos textos editados, notouse uma grande quantidade de cartas, 54 no total, sendo o gênero mais recorrente no caderno. Dentre essas cartas, a temática religiosa está presente em 40 delas, e, por ser o tema mais abundante, optou-se por fazer um recorte do corpus para estudo dos 40 borradores de cartas religiosas do caderno Farmácia São José.

No plano de trabalho IC 2016/2017 PIBIC/CNPq/PROCAD, que tem por título Por uma Ação Católica: Edição dos rascunhos de cartas de Eulálio Motta, preservadas no caderno Farmácia São José, foi proposta uma Edição Digital das cartas religiosas existentes no caderno, e para que essa edição seja viabilizada, se fez necessário a confecção de um dossiê arquivístico dos textos selecionados para o estudo.

De acordo com Barreiros (2012; 2015), o dossiê arquivístico consiste na reunião de prototextos e paratextos que irão auxiliar a compreensão do texto que está sendo publicado. A Edição Digital propõe uma dinamicidade na leitura e compreensão dos documentos publicados, e, para isso, o dossiê arquivístico é de suma importância, pois, por meio dele, o leitor/usuário terá acesso a textos, imagens e informações contidas no acervo que proporcionarão uma leitura mais completa.

\section{METODOLOGIA}

Primeiro, realizou-se a revisão das edições do caderno Farmácia São José, efetuada no plano de trabalho de Iniciação Científica 2015/2016, juntamente com outro membro do projeto Edição das Obras Inéditas de Eulálio Motta, como sugere as diretrizes propostas pela Modern Language Association (MLA), com o propósito de assegurar uma edição confiável. Apesar do bom estado de conservação do caderno Farmácia São José, os textos são manuscritos e alguns deles foram feitos a lápis, e, por conta disso, há certa dificuldade em sua edição e correção, necessitando de correções mais apuradas.

Foram elaboradas duas fichas para a confecção do dossiê arquivístico, com o intuito de sistematizar a busca na documentação do acervo. A primeira ficha apresenta uma lista com o resultado do levantamento dos textos encontrados no acervo; a segunda ficha apresenta os metadados referentes aos textos elencados no dossiê. As informações contidas na ficha de metadados facilitam a identificação e localização do documento 
citado dentro do acervo, assim como o assunto abordado no documento, em qual suporte se encontra, se já foi editado, autoria, etc.

\section{RESULTADOS E/OU DISCUSSÃO}

Primeiramente, elaborou-se o dossiê interno do caderno Farmácia São José por meio da leitura das cartas religiosas e a identificação das relações transtextuais existentes. Por se tratar, em sua maioria, de documentos monotestemunhais, não foram identificadas relações prototextuais dos borradores das cartas do caderno Farmácia São José fora do próprio caderno, mas sim paratextuais.

Nos borradores de cartas, Eulálio Motta referencia diversas obras literárias de abordagens católicas e protestantes. Uma das obras identificadas consta no acervo, outra está disponível online para leitura, mas existem outras que ainda não foram localizadas. É importante salientar que por meio do dossiê arquivístico é possível realizar um levantamento do documento ausente, ou seja, é citado no texto estudado, porém não se encontra no acervo.

Para exemplificar as relações transtextuais encontradas no caderno Farmácia São José e em textos fora dele que foram citados nos borradores de cartas, segue abaixo o exemplo da Ficha 1 do dossiê arquivístico do fólio 17v (cf. Tabela 1):

Tabela 1. Dossiê Arquivístico do fólio 17v - Ficha 1.

\begin{tabular}{|c|c|c|}
\hline TEXTO ${ }^{1}$ & \multicolumn{2}{|c|}{ Meu caro Afonso Carapiá: Saudações (f. 17v) } \\
\hline LISTAR & OCUMENTOS DO DOSSIÊ & JUSTIFICATIVA DE INSERÇ̃̃O NO DOSSIÊ \\
\hline 1. & $\begin{array}{l}\text { Livro de Ernesto de Oliveira } \\
\text { (nome do livro não divulgado nas } \\
\text { cartas) que pretendia ser resposta } \\
\text { ao livro "A Igreja, a Reforma e a } \\
\text { Civilização" de Leonel Franca. } \\
\text { Este livro foi emprestado a } \\
\text { Eulálio Motta por Afonso } \\
\text { Carapiá. }\end{array}$ & $\begin{array}{l}\text { Eulálio enviou esta carta a Afonso Carapiá pedindo para que } \\
\text { ele lêsse o livro "Catolicismo e Protestantismo" de Leonel } \\
\text { Franca e o comparasse com o livro de Ernesto de Oliveira. }\end{array}$ \\
\hline 2. & $\begin{array}{l}\text { Livro “A Igreja, a Reforma e a } \\
\text { Civilização" de Leonel Franca. }\end{array}$ & $\begin{array}{l}\text { Eulálio cita este livro de Leonel para falar do livro de } \\
\text { Ernesto de Oliveira. }\end{array}$ \\
\hline 3. & $\begin{array}{l}\text { Livro "Catolicismo } r \\
\text { Protestantismo" }\end{array}$ & $\begin{array}{l}\text { Este livro é o motivo pelo qual Eulálio remeteu esta carta a } \\
\text { Afonso Carapiá, para pedir autorização de enviá-lo para que } \\
\text { Afonso Carapiá o lesse e mostrasse suas impressões sobre o } \\
\text { livro. "Catolicismo e Protestantismo", segundo Eulálio, foi } \\
\text { escrito por Leonel Franca em resposta ao livro de Ernesto de } \\
\text { Oliveira. }\end{array}$ \\
\hline 4. & $\begin{array}{l}\text { Presado amigo Euricles Barreto } \\
\text { Saudações (f. 18r). }\end{array}$ & $\begin{array}{l}\text { Eulálio Motta enviou esta carta para Euricles Barreto } \\
\text { indicando a leitura dos mesmos livros de Leonel Franca: "A } \\
\text { Igreja, a Reforma e a Civilização", "Catolicismo e } \\
\text { Protestantismo", que indicou para Afonso Carapiá na carta } \\
\text { de fólio } 17 \mathrm{r} \text {. }\end{array}$ \\
\hline
\end{tabular}

\section{CONSIDERAÇÕES FINAIS}

As cartas do autor são de extrema importância pois revelam aspectos íntimos de sua personalidade, assim como sua relação com seus interactantes. Os borradores de cartas religiosas de Eulálio Motta expõem seus posicionamentos e crenças religiosas e mostra como ele os defendia, além de possibilitar uma contextualização de obras, como alguns panfletos publicados pelo autor e outras obras inéditas, como crônicas e poemas, 
que também compunham a Ação Católica que promoveu. Por esses motivos, o presente estudo contribui para projeto Edição das obras inéditas de Eulálio Motta que visa à edição das obras inéditas do autor Eulálio Motta, a partir das fontes preservadas em seu acervo pessoal.

\section{REFERÊNCIAS}

BARREIROS, Patrício Nunes. O Pasquineiro da Roça, a hiperedição dos panfletos de Eulálio Motta. Feira de Santana: UEFS Editora, 2015.

BARREIROS, Patrício Nunes. Sonetos de Eulálio Motta. Feira de Santana: UEFS Editora, 2012.

BARREIROS, Patrício Nunes. A relevância do dossiê arquivístico em edições digitais de documentos de acervos de escritores. Revista Internacional del Libro, Digitalización y Bibliotecas, v. 2, p. 20-33, 2014.

CAMBRAIA, César Nardelli. Introdução à crítica textual. São Paulo: Martins Fontes, 2005.

FINNERAN, Richard J. (Org.). The literary text in the digital age. Michigan: University Michigan, 1996.

LUCÍA MEGÍAS, José Manuel. Elogio del texto digital, claves para interpretar el nuevo paradigma. Madrid: Fórcola, 2012.

MCGANN, Jerome. A critique of modern textual criticism. 5. ed. Chicago: University of Chicago Press, 1992.

MCGANN, Jerome. The textual condition. Princeton: Princeton University Press, 1991

PAIXÃO DE SOUSA, Maria Clara. A Filologia Digital em Língua Portuguesa: alguns caminhos. In: GONÇALVES, Maria Filomena; BANZA, Ana Paula. (Coord.). Bibliotecas, estudo e colóquios. Evora: CIDEHUS, 2013.

SHILLINGSBURG, Peter L. Scholarly editing in the computer age: theory and practice. 3. ed. Michigan: University Michigan, 2004.

SPAGGIARI, Barbara; PERUGI, Maurizio. Fundamentos da crítica textual. Rio de Janeiro: Lucerna. 2004.

SPINA, Segismundo. Introdução à edótica: crítica textual. 2. ed. rev. e atual. São Paulo: ArsPoetica/EDUSP, 1994. 